\title{
Docosahexaenoic Acid Modulates Oxidative Stress and Monoamines Levels in Brain of Streptozotocin-Induced Diabetic Rats
}

\author{
Sahar Mohamed Mahmoud ${ }^{1}$, Yasmin Abdel Latif ${ }^{2}$, Hisham Orban², \\ Amr Mahmoud Ibrahim², Jihan Hussein ${ }^{2}$ \\ ${ }^{1}$ Zoology Department, Faculty of Science, Cairo University, Cairo, Egypt \\ ${ }^{2}$ Medical Biochemistry Department, National Research Centre, Cairo, Egypt
}

SUMMARY

The prevalence of diabetes mellitus (DM) is increasing in many countries. A lower prevalence of DM type 2 and other glucose metabolism disorders was observed in populations consuming larger amounts of n-3 polyunsaturated fatty acids, existing mainly in fish. Docosahexaenoic acid (DHA) is an important signaling molecule required for the central nervous system continuous maintenance of brain funcntioning. The aim of this research is to highlight the role of DHA in controlling glycemic measures and modulating the oxidant/antioxidant status and levels of neurotransmitters in brains of diabetic rats. Diabetes was induced with a single s.c. injection of streptozotocin (STZ) $(6.0 \mathrm{mg} / 0.5 \mathrm{ml} / 100 \mathrm{~g}$ body weight). Experimental male Wister rats $(n=40)$ were randomly divided into four groups: control group, DHA, STZ-diabetic, and STZ + DHA. All rats were decapitated after 30 days to evaluate glucose and insulin levels, brain oxidative stress and also to estimate monoamines levels. DHA administration significantly improved fasting blood glucose and insulin levels compared to the DHA+STZ group and decreased 8-hydroxy-2'-deoxyguanosine level in their urine. In addition, DHA treatment to STZ-treated rats showed a decrease in malondialdehyde content and advanced oxidation protein product and significantly increased glutathione content in brains of DHA + STZ-treated rats, and decreased the level of monoamines in rat's brain. To conclude: DHA modulated the elevated oxidative stress and neurotransmitters levels, and also acetylcholinesterase activity in diabetic rat brain via enhancing insulin level in serum.

Key words: diabetes, docosahexaenoic acid, oxidative stress, neurotransmitters, insulin

Corresponding author:

Sahar Mohamed Mahmoud

e-mail:Sahar@sci.cu.edu.eg 


\section{INTRODUCTION}

Diabetes mellitus (DM) is a complex metabolic disorder which affects multiple physiological systems including the central nervous system (1). According to WHO, more than 180 million people worldwide have DM and this may double by 2030 . DM Type 2 is the most frequent form, constituting $85 \%$ of all DM cases, while type $1 \mathrm{DM}$ and specific/gestational DM constitute $10 \%$ and $5 \%$, respectively. Studies indicated that clinical complications and morbidity due to DM could be decreased by adjusting glucose level tightly. Both types of diabetes were reported to induce neuronal and brain changes, as those in Alzheimer's disease (2).

The incorporation of sea foods in the human nutrition, especially the polyunsaturated fatty acids (PUFAs) of 20 or more carbon atoms was a significant turning point in human evolution (3). Both eicosapentaenoic acid (EPA) and docosahexaenoic acid (DHA) are n-3 common long chain-PUFAs (found in fish, shellfish, micro- and macro-algae and some mammals). DHA deficiency is correlated with several neurological disorders, including Alzheimer's and Parkinson's disease, schizophrenia, and depression (4). Unlike liver, the brain cannot efficiently convert dietary alpha linolenic acid to DHA (5), and is completely dependent on the uptake of DHA from the plasma. DHA was identified as the fundamental neuroprotective fatty acid used against cerebral aging, and neurodegenerative diseases, especially in ischemia (6).

The present study aimed to shed light on the beneficial effect of DHA intake on blood sugar and insulin levels in blood sera as well as 8-hydroxy-2'deoxyguanosine (8- OHdG) level (as a product of oxidative DNA damage) in urine of STZ-induced diabetic rats, and whether DHA treatment could improve insulin and blood sugar levels in rats' sera together with ameliorating oxidative stress and neurotransmission in the adult rat brain during experimental induction of diabetes.

\section{MATERIALS AND METHODS}

\section{Chemicals}

Docosahexaenoic acid was brought from Fischer Scientific Company (USA), while streptozotocin was purchased from Sigma (Germany). All lab- oratory chemicals used for HPLC were of analytical grade, and water provided for all experiments was also of ultrapure quality.

\section{Experimental animals and ethical approval}

The animal house of National Research Center (NRC) supplied the male albino rats $(180 \pm 10 \mathrm{~g})$ used in the study. Animals were acclimatized for 10 days to the experiment as they were kept in stainless steel cages at $22+2^{\circ} \mathrm{C}$ and light/dark cycle $(12 \mathrm{~h} / 12$ h). The guidelines and regulations of the ethical committee of NRC (Ethical No. 16303) were followed in this study.

\section{Experimental design and induction of diabetes}

Forty rats were divided into four groups (10 rats in each group): group I, control rats; group II (DHA) in which rats received $10 \mathrm{mg}$ DHA $/ \mathrm{kg}$ bw/day; group III (STZ), streptozotocin (STZ) was dissolved in $50 \mathrm{mM}$ sodium citrate $(\mathrm{pH}$ 4.5) solution containing $150 \mathrm{mM} \mathrm{NaCl}$, and rats had a single s.c. injection of STZ $(6.0 \mathrm{mg} / 0.5 \mathrm{ml} / 100 \mathrm{~g}$ body weight). Fasting blood sugar was checked after 3 days to confirm DM induction in rats (7). Group IV (STZ + DHA) included STZ- injected rats who were orally administered DHA. After 30 days of treatment, urine samples were collected from all rats for $24 \mathrm{~h}$, for 8OHdG estimation. Rats were overnight fasted, and blood was collected from the orbital vein. All animals were decapitated and the brain was excised immediately and rinsed with ice-cold saline. For determining fasting blood glucose, plasma was separated using cooling centrifuge (Laborzentrifugen, 2K15, Germany).

\section{Tissue Homogenate}

Brain was quickly removed, perfused with iced saline to remove blood cells, blotted on filter paper, and finally frozen at $-80^{\circ} \mathrm{C}$. A $5 \mathrm{ml}$ of cold buffer $\left(0.5 \mathrm{~g}\right.$ of $\mathrm{Na}_{2} \mathrm{HPO}_{4}$ and $0.7 \mathrm{~g}$ of $\mathrm{NaH}_{2} \mathrm{PO}_{4}$ per $500 \mathrm{ml}$ of deionized water) $(\mathrm{pH}$ 7.4) were used to homogenize the brain frozen tissue. After homogenization, all brain samples were centrifuged at 4000 rpm for $15 \mathrm{~min}$ at $4^{\circ} \mathrm{C}$. The supernatant was kept for different biochemical parameters estimation $(8,9)$. 


\section{Biochemical estimations}

Fasting blood glucose level and insulin level as well were determined according to the enzymatic colorimetric method of Trinder (10) and the ELIZA technique, respectively.

\section{Determination of brain oxidant/antioxidant stress parameters}

Brain malodialdehyde (MDA) was determined according to Ohkawa et al. (11), while reduced glutathione $(\mathrm{GSH})$ was carried out according to Beutler (12) using commercial kits (colorimetric) from Biodiagnostics, Egypt. Using an ELISA kit from NOVA bioneovan Co. Ltd, China, the advanced oxidation protein product level in the brain (AOPP; estimating the degree of oxidant-mediated protein damage) was determined, according to the manufacturer procedure.

\section{Determination of 8- hydroxyl-2'-Deoxy- guanosine level in urine}

By a modified method described previously and according to Hussein et al. (13), an HPLC analysis was carried out to evaluate 8-hydroxy-2'deoxyguanosine $(8-\mathrm{OHdG})$ content. In brief, ultrapure water was used to dissolve the 8-OHdG standard. Serial dilutions with different concentrations were prepared and injected onto HPLC for drawing a standard curve. 8-OHdG in urine samples were extracted from $1 \mathrm{ml}$ urine using Strata C18-E (55 um, 70 A) column. The eluents were dried under nitrogen gas and then reconstituted in $5 \mathrm{ml}$ ultrapure water. $20 \mu \mathrm{l}$ were injected onto HPLC from each sample.

\section{HPLC condition}

An acetonitrile/methanol/phosphate $(8.8 \mathrm{~g}$ of potassium di-hydrogen phosphate $\left(\mathrm{KH}_{2} \mathrm{PO}_{4}\right)$ in 1000 $\mathrm{pH}$ 3.5) buffer (25/10/965) v/v was used as the mobile phase. The buffer was filtered two times using 0.45 $\mu \mathrm{m}$ pore size sterile membrane filter at a flow rate of $1 \mathrm{ml} / \mathrm{min}$ through HPLC reverse phase column (250 $\times 4.6$, particle size $5 \mu \mathrm{l}$ ) with an electrochemical detector of cell potential of $600 \mathrm{mV}$. The $8-\mathrm{OHdG}$ concentration was calculated from the standard curve and then divided by the urinary creatinine content estimated by a kinetic method (14).

\section{Determination of brain monoamines}

Brain serotonin, noradrenaline, and dopamine were determined according to Hussein et al. (15). Analysis was undertaken with Agilent technologies 1100 series HPLC system, with a quaternary pump (G131A model), using ODS-reversed phase column $(\mathrm{C} 18,25 \times 0.46 \mathrm{~cm}$ i.d. $5 \mu \mathrm{m})$, and a mobile phase of potassium phosphate buffer/methanol 97/3 (v/v) with flow rate $1 \mathrm{ml} / \mathrm{min}$. After sample injection (20 $\mu \mathrm{l})$, peaks were visualized at wavelength of $270 \mathrm{~nm}$. Brain serotonin in addition to noradrenaline and dopamine concentrations in different groups were calculated using external standard method using peak areas. Serotonin, noradrenaline, and dopamine standards were prepared in serial dilutions, and each dilution was injected in the HPLC column to determine the peak area of each one. Linear standard curves were made: plotting peak areas versus the corresponding concentrations. Concentrations of brain samples for each parameter were then determined according to its corresponding standard curve.

\section{Determination of brain acetylcholinesterase Activity}

Activity of AChE in brain of rats were determined by Ellman et al., (16) using a colorimetric kinetic assay (Biochemical Enterprise Milano, Italy).

\section{Statistical analysis}

Data analysis was performed using version 16 of the SPSS (statistical package for the social sciences) program, and Microsoft Excel 2007. Significant difference between values was evaluated using one-way ANOVA and Student's t-test and the value at $p<0.05$ indicated a statistically significant difference.

\section{RESULTS}

The present results, as illustrated in Figure 1, indicated that fasting blood glucose level in STZinjected rats $(6.0 \mathrm{mg} / 0.5 \mathrm{ml} / 100 \mathrm{~g}$ body weight) exhibited a sharp elevation of a significant change at $p<0.05$ with a percentage difference of $187.7 \%$ versus control value. In accordance with diabetes 

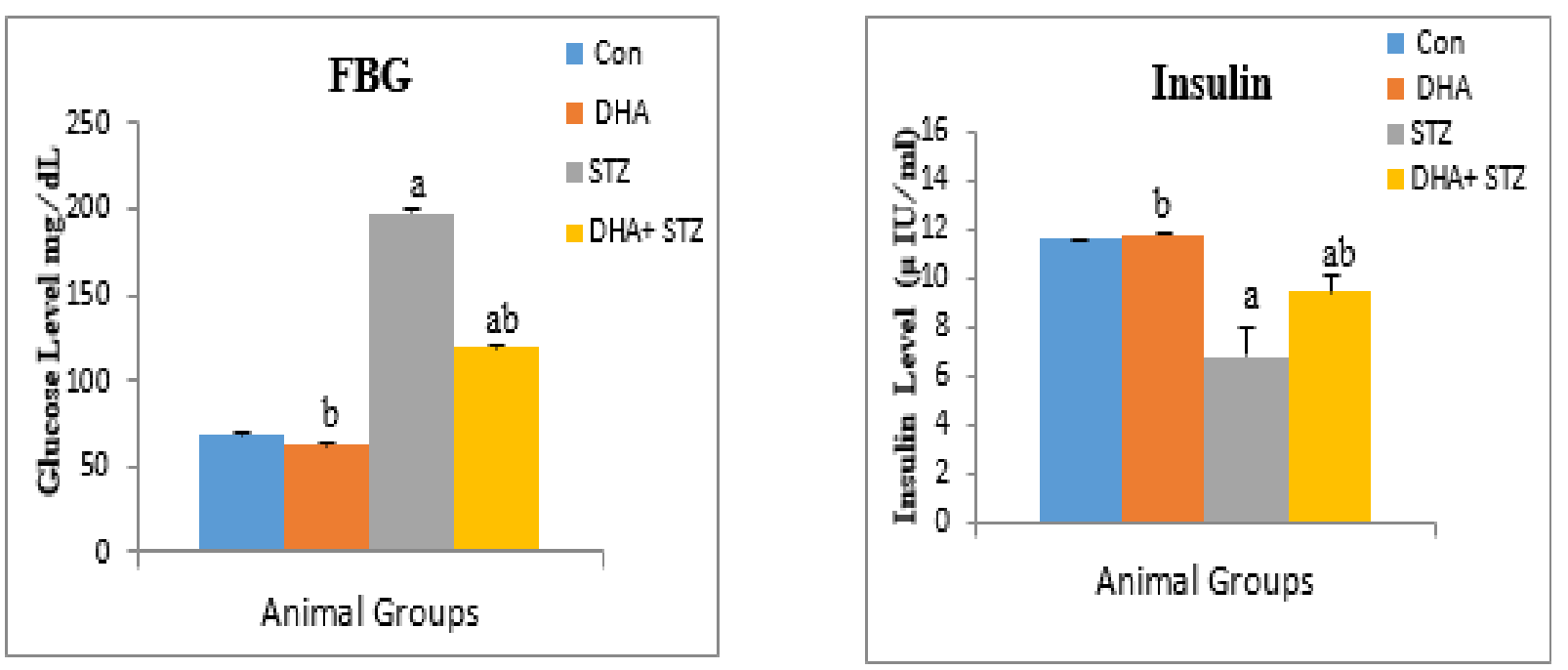

Figure 1. The Effect of docosahexaenoic (DHA) on fasting blood glucose (FBG; $m g / d l)$ and insulin $(\mu \mathrm{IU} / \mathrm{ml}$ ) levels in sera of streptozotocin (STZ)-induced diabetic rats. a: significant change at $p<0.05$ with respect to control group. b: significant change at $p<0.05$ with respect to STZ-treated group
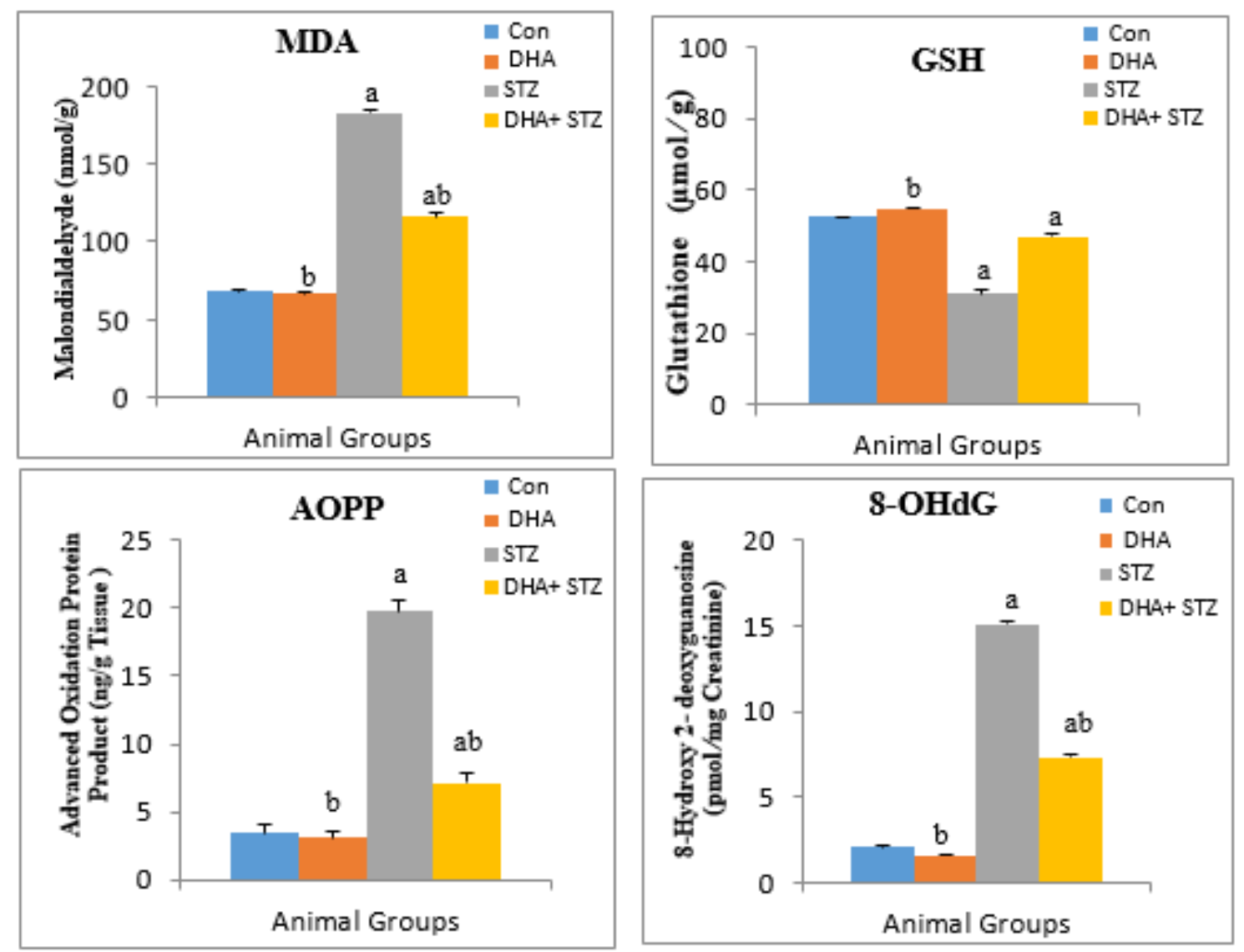

Figure 2. The effect of docosahexaenoic (DHA) on malondialdehyde (MDA), glutathione (GSH) and advanced oxidation protein product (AOPP) contents in the brain and 8-hydroxy-2'-deoxyguanosine (8-OHdG) level in urine of STZinduced diabetic adult male rats. a: significant change at $p<0.05$ with respect to control group. $b$ : significant change at $p$ $<0.05$ with respect to STZ-treated group 
induction in rats, insulin level in sera of the same group revealed a significant decrease $(p<0.05)$, with a percentage difference of $-41.74 \%$ when compared with the control value, indicating the successful induction of diabetes in the STZ-treated rat group. Meanwhile, DHA alone showed a slight decrease of fasting blood sugar and an increase in insulin level of non-significance compared to control, but were significant when compared to STZ- treated group. DHA + STZ treated rats indicated the potency of DHA in lowering blood glucose and elevating insulin level with significant changes $(p<0.05)$ versus STZ-group values.

As shown in Figure 2, induction of diabetes in the present study was found to provoke a sharp increase in malondialdehyde (MDA), and antioxidant protein product (AOPP) accompanied by a marked decrease in glutathione (GSH) level in the brain of adult male rats, which was significant $(\mathrm{p}<$ $0.05)$, with percentage differences of $167.23 \%$, $480.88 \%$, and $-40.23 \%$, respectively, when compared to control values. A tremendous increase was also recorded in 8-hydroxy-2'-deoxyguanosine (8-OHdG) contents in urine, with a significant change $p<0.05$, with percentage differences of $619.07 \%$, compared to the control group value.

The present results illustrated in Figure 2 indicated that DHA administration to STZ-diabetic rats increased GSH and inhibited markedly MDA, AOPP contents in the brain of rats and also decreased $8-\mathrm{OHdG}$ formation in urine. The observed increase in GSH content and the decrease in MDA, AOPP and 8-OHdG contents were significant $(\mathrm{p}<$ 0.05 ) when compared with both STZ-diabetic rat values and control group values, with percentage differences of $-10.44 \%, 69.84 \%, 108.82 \%$, and 247.62 $\%$, respectively, if compared to control group.

Investigation of the neurotransmitter content in the diabetic rat brain revealed marked elevation in $\mathrm{NE}$, DA and 5-Hydroxytryptamine (5-HT) accompanied with a marked sharp increase in AChE activity as illustrated in Figure 3. These elevations were significant at $\mathrm{p}<0.05$ with percentage differences of $66.47 \%, 58.06 \%, 159.32 \%$, and $110.94 \%$, respectively, compared to control values.
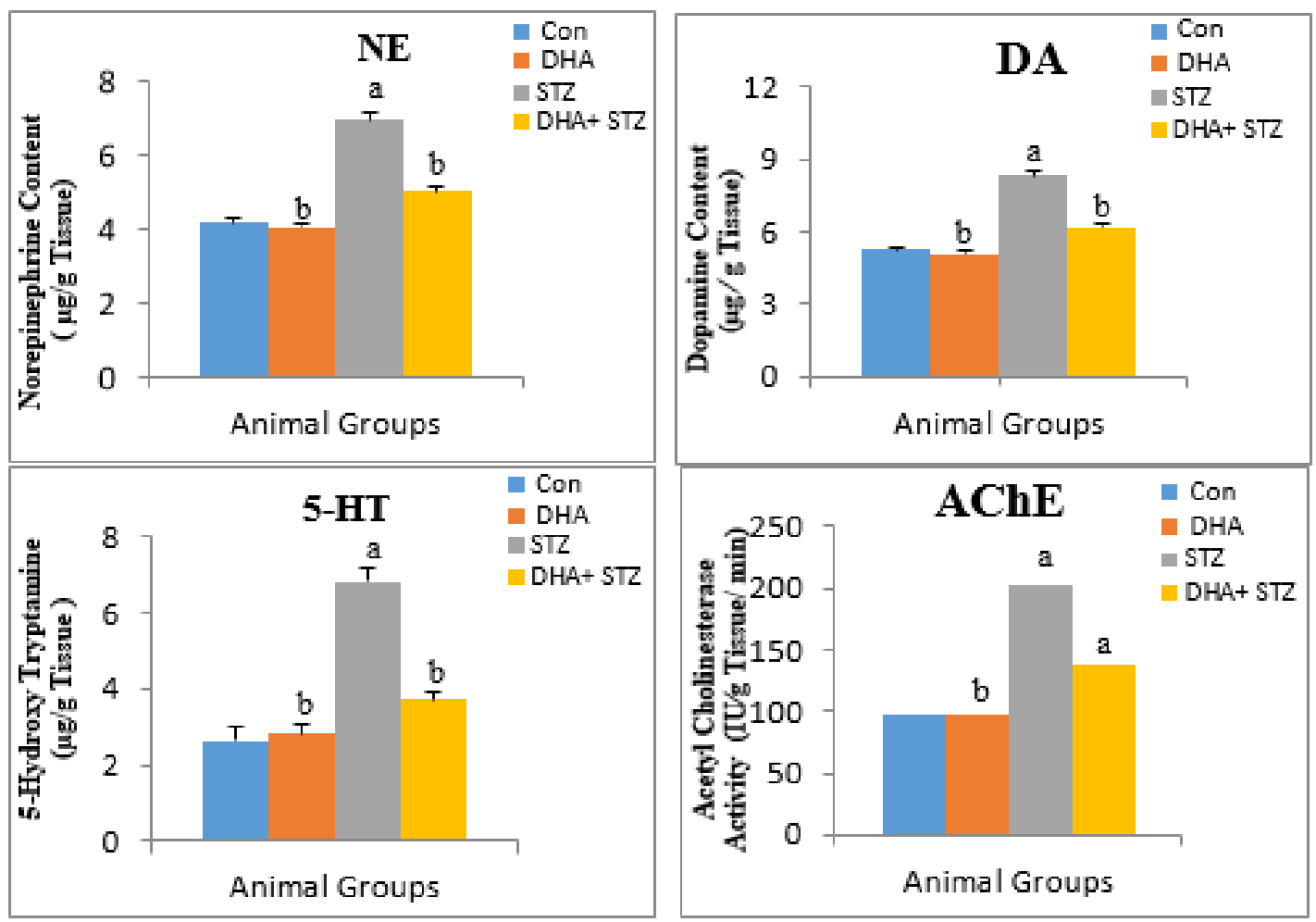

Figure 3. The effect of docosahexaenoic (DHA) on norepinephrine (NE), dopamine (DA), 5- hydroxytryptamine (5-HT) contents and acetyl cholinesterase ( $A C h E)$ activity in brain of STZ-induced diabetic rats. a: significant change at $p<0.05$ with respect to control group. $b$ : significant change at $p<0.05$ with respect to STZ-treated group 


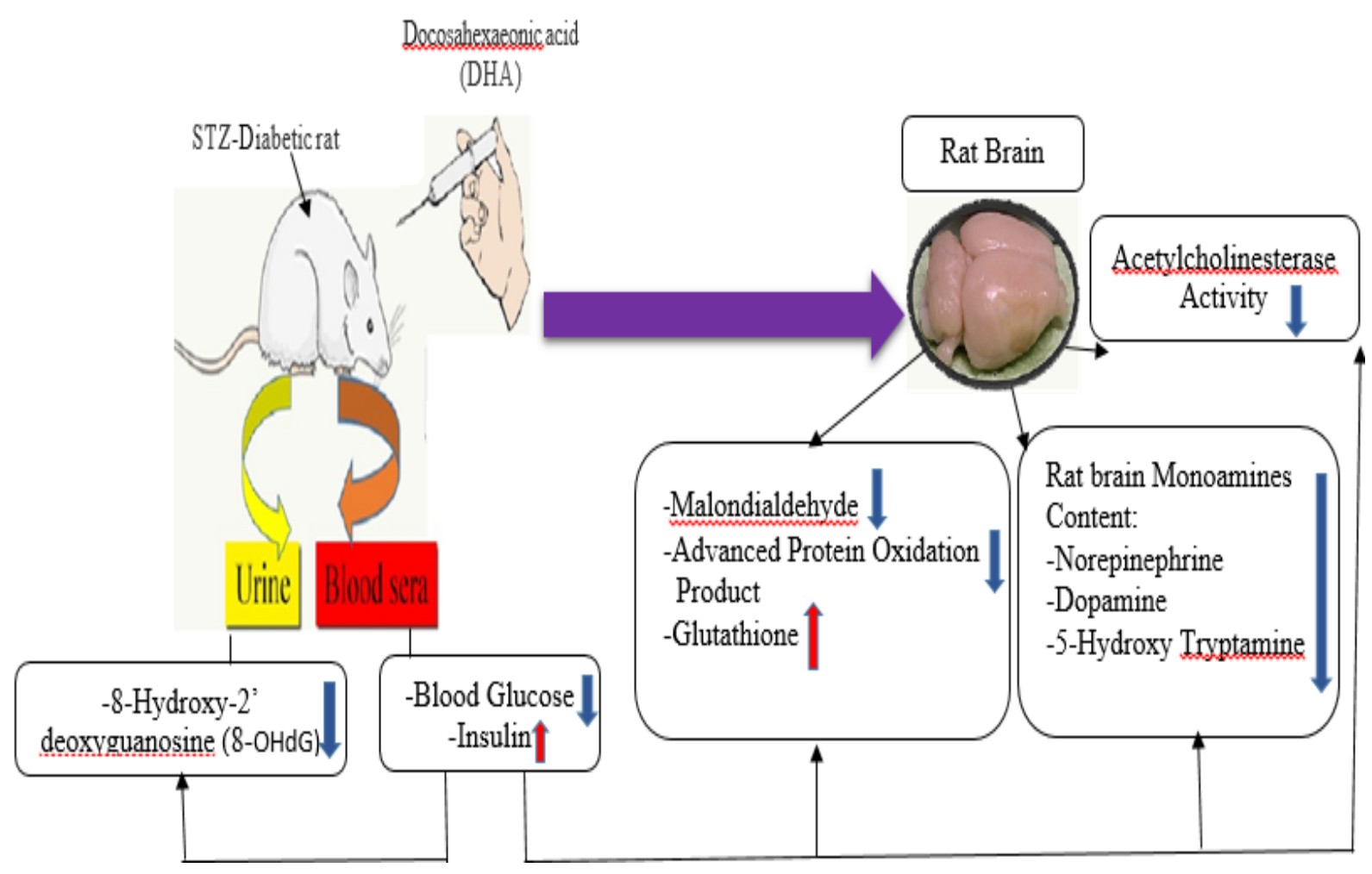

Figure 4. An illustrative graph showing the impact of docosahexaenoic acid on different investigated parameters in STZ-diabetic rats

Meanwhile, DHA administration to male rats caused non-significant changes in their brain monoamines level as it slightly decreased NE and DA, and increased 5-HT level and AChE activity as well, when all compared to control values. DHA + STZ treated rats group revealed DHA ability to decrease the elevated levels of NE, DA, 5-HT contents in their brain as well as AChE activity with a significant change $(p<0.05)$ if compared to STZ- group values and control group, but with percentage differences of $66.47 \%, 58.06 \%, 159.32 \%$, and $110.94 \%$, respectively, when compared to control values (Figure 3). An illustrative graphic that shows the impact of DHA acid on different investigated parameters in STZ-induced diabetic rats was presented in Figure 4.

\section{DISCUSSION}

In the present study, diabetes mellitus successful induction was reflected by a significant rise in blood glucose levels and low insulin levels, which is in line with El-Yamany et al. (17) and Mohamed et al. (18). DM was reported to be accompanied with altered memory function, cardiac stress, endothelial disturbed function and many complications $(1,19)$ could be linked to impaired insulin as insulin signaling affects synaptogenesis and neuronal survival, which leads to memory loss (1).

Data indicated that DHA induced a significant decrease in fasting blood glucose level, which was in accordance with Hussein et al. (20) who documented synergistic effect of nano-encapsulated DHA on DM, together with a significant increase in serum insulin level which could be due to the G-protein-coupled receptor which mediates insulin-sensitizing effects and the anti-inflammatory adipocytes and monocytes/macrophage (21). Moreover, an improved glucose uptake in T2DM could be related to increased residency time of glucose transporters in the plasma membrane. Furthermore, the effect of n-3 PUFA on the adiponectin genes were associated with insulin resistance (2), also inducing glutathione and thioredoxin expression as antioxidant systems in the hippocampus, since DHA acts as an agonist of peroxisome proliferator-activated receptor- $\gamma$ (22), thus regulating cytokine expression. Also DHA treatment was found to suppress the inflammatory signaling pathways in acute pancreatitis (23).

Inflammation, oxidative stress, and altered glucose metabolism were reported as important 
features of both Type II DM and Alzheimer disease (1). Present results indicated significant increases in malondialdehyde and advanced oxidative protein products contents in the brain of STZ-induced diabetic rats accompanied with decreased glutathione level. Diabetic encephalopathy may result as a degenerative brain disease in long-standing diabetic patients. The impact of ROS on neuronal cells in diabetes caused impaired learning and memory, also problem solving, with mental and motor speed problems, especially in type 1 diabetic patients (24). Increased lipid peroxidation was linked to apoptosis under hyperglycemic extremes in the brain, associated with mild cognitive impairment (25). In many pathological conditions, stress within cells triggers mitochondrial oxidative damage resulting in apoptosis and/or necrosis leads to inhibition of neurogenesis (26). Also, DHA was found to increase the levels of antioxidant enzymes as catalase and reduced glutathione levels with increased expression of glutathione peroxidase in the brain hippocampus (27). In addition, it decreased the ROS levels in the cortex and hippocampus of diabetic rats and attenuated the neuronal loss cognition and the locomotor deficits (28). For continuous neurotransmission activity, the brain uses an uninterrupted supply of oxygen (29).

The present study indicated significant elevation in NE, DA, 5-HT levels in accordance with El-Yamany et al. (17). The enhanced level of NE could be attributed to the accumulation of NE resulting from inhibition of presynaptic release of $\mathrm{NE}$ and/or increased re-uptake, or a decrease in metabolic degradation of NE. Meanwhile, DA marked elevations may correlate to dysfunction of the brain dopaminergic system, increased D2 receptor density, and increased tyrosine hydroxylase and monoamine oxidase activities. Moreover, 5-HT elevations reflect a reduction in its turnover or functional changes in the diabetic rat brain. As a structural fatty acid in bilayer membranes, DHA was found to concentrate in photoreceptors and in neurons and glia of the nervous system (6). The unique grouping of fatty acids in brain selectively esterifies arachidonic acid and DHA into the sn-2 position of brain phospholipids in neuronal membranes, but not in neuronal cytoplasm (30).

Both choline and long-chained polyunsaturated fatty acids are crucial nutrients for neurodevelopment and mental health during all life time, as they accumulate in tissues for maintenance of brain cell function (31). The deficient DHA level observed in healthy elderly people suffering from a decline in memory, learning impairment, may lead to increased occurrence of neurodegenerative diseases, as detected in patients with Alzheimer's disease (32). Visual and neurocognitive deficits were also reported in inadequate DHA intake (33). Regulation of the synaptic transmission was reported as a result of a complex metabolic cooperation between three items: the endothelial cell as an energy supply, the astrocyte network for regulation of functional coordination of cells and plasticity, and the presynaptic neuron responsible for the release of neurotransmitters. Modifications of DHA levels inside phospholipid membranes led to glucose transport change (34) and changes in gap junction coupling (35).

Present data indicated that DHA treatment diminished a significant elevation in AChE activity in brain of diabetic rats which evolved from increased substrate level and increased synthesis of the enzyme, due to changes in retrograde axonal transport, which delivers information to the nerve body and thus serves as a protective mechanism for maintaining adequate glucose delivery (18), indicating the ameliorating effect of DHA on AChE activity. Meanwhile, regional DHA signaling was mediated by phospholipase A2, a critical enzyme for muscarinic cholinergic signaling $(36,37)$, which increases the incorporation of DHA into synaptic membranes and improves signal transduction, enhancing glutamatergic (38) and dopaminergic (39) synaptic activities, as well as noradrenaline release in cultured cells (40).

The membrane-bound enzymes related neurotransmission, signal transduction controlling neurotransmission, and neuronal growth factors are all affected by the fluidity of the cell membrane which was reported to be augmented by DHA, as its deficiency may participate in micro-aggregation formation and conformational changes of receptors/ enzymes in the membrane (41). Fluidity of the neuronal membrane is important for receptors to enable them to recognize neurotransmitter-containing vesicles and transmitting messages as its rigidity leads to less competition of neurotransmitters and transmitting signals by the receptors. The neuronal plasma membrane fluidity was correlated with the neurobehavioral effects and avoidance-related memory function (42). An increased size and complexity of the brain tissue after DHA treatment was proposed by Bandarra et al. (43), which could further 
lead to increased mental, behavioral and motor skills development due to maintaining the integrity and function of neurons.

NeuroprotectinD-1 (NPD-1; DHA-derivative), a bioactive effector in neuronal tissues may generate cerebral protection during ischemia (44) and its formation was stimulated by increased oxidative stress and inflammatory cytokines through the tandem phospholipase A2-lipoxygenase action on free DHA (6). Also, NPD1 was reported to reduce formation of $\beta$-amyloid peptide involved in Alzheimer's disease progression, stimulating anti-apoptotic genes expression while reducing the expression of pro-apoptotic genes, which therefore inhibits apoptosis due to oxidative stress (45). NPD-1, enhanced the production of a disintegrin alpha-secretase, a metallo-protease showing both neurogenic and neurotrophic properties, evidenced by modulated hippocampal function, increasing thus the newly born neurons in dentate gyrus of adult rats by neurogenesis (32).

Results showed a significant lowering effect of DHA on 8-OHdG level in urine of DHA + STZ- rats, minimizing DNA oxidative damage and oxidative stress in tissues, which may be attributed to increased levels of mRNA of the antioxidant molecules or diminished DNA double-strand breaks, which decreased both the $\gamma$-H2AX foci formation and ATM activation (a major kinase orchestrating DNA damage response) (29). The results also suggested a DHA genomic protective effect through the up-regulation of nuclear factor-2 thus attenuating oxidative stress- induced DNA damage. Moreover, DHA was found to influence differentiation of neural stem cells into neurons, both in vitro and in vivo, and suppress the cell death (29).

\section{CONCLUSION}

The present study showed that docosahexaenoic acid administration to streptozotocin-injected rats enhanced serum insulin level indicating the antioxidant role of docosahexaenoic acid against streptozotocin action on the pancreas which led to lowering of blood glucose level and reducing 8hydroxy-2'-deoxyguanosine level in their urine and modulation of brain oxidant/antioxidant status, acetylcholinesterase activity and monoamines of diabetic rats.

\section{Conflict of Interest}

The authors declare no conflict of interest.

\section{Funding}

No funds, grants, or other support were received.

\section{Authors contribution}

All authors contributed equally in this work 


\section{References}

1. Pardeshi R, Bolshette N, Gadhave $K$ et al. Docosahexaenoic Acid Increases the Potency of Soluble Epoxide Hydrolase Inhibitor in Alleviating Streptozotocin-Induced Alzheimer's Disease-Like Complications of Diabetes. Front Pharmacol 2019; 10: 1-13

https://doi.org/10.3389/fphar.2019.00288

2. Sarbolouki S, Javanbakht MH, Derakhshanian $\mathrm{H}$ et al. Eicosapentaenoic acid improves insulin sensitivity and blood sugar in overweight type 2 diabetic mellitus patients: A double-blind randomised clinical trial. Singapore Med J 2013; 54(7):387-90.

https://doi.org/10.11622/smedj.2013139

3. Mozaffarian D, Wu JH. (n-3) fatty acids and cardiovascular health: are effects of EPA and DHA shared or complementary? J Nutr 2012; 142(3): 614S-25S.

https://doi.org/10.3945/jn.111.149633

4. Grosso G, Micek A, Marventano S et al. Dietary n3 PUFA, fish consumption and depression: A systematic review and meta-analysis of observational studies. J Affect Disord 2016; 205: 269-81. https://doi.org/10.1016/j.jad.2016.08.011

5. Smink W, Gerrits WJ, Gloaguen M et al. Linoleic and $\alpha$-linolenic acid as precursor and inhibitor for the synthesis of long-chain polyun-saturated fatty acids in liver and brain of growing pigs. Animal 2012; 6(2): 262-70.

https://doi.org/10.1017/S1751731111001479

6. Bazan G, Eady N, Khoutorova L et al. Novel aspirin-triggered neuroprotectin D1 attenuates cerebral ischemic injury after experimental stroke. Exp Neurol 2012; 236(1):122-30.

https://doi.org/10.1016/i.expneurol.2012.04.007

7. Uchiyama S, Yamaguchi M. Alteration in serum and bone component findings induced in streptozotocin-diabetic rats is restored by zinc acexamate. Int J Mol Med 2003; 12(6):949-54.

https://doi.org/10.3892/ijmm.12.6.949

8. Mannaa F, Ahmed HH, Estefan SF et al. Saccharomyces cerevisiae intervention for relieving flutamide-induced hepatotoxicity in male rats. Pharmazie. 2005; 60(9):689-95

9. Hussein J, Refaat E, Morsy S et al. Green tea attenuates experimental hepatitis in context of oxidative stress. J Appl Pharm Sci 2013; 3(12):124. https://japsonline.com/admin/php/uploads/1146 pdf.pdf

10. Trinder P. Determination of glucose in blood using glucose oxidase with an alternative oxygen acceptor. Ann Clin Biochem 1969; 6:24-27. https://doi.org/10.1177/000456326900600108

11. Ohkawa H, Ohishi N, Yagi K. Assay for lipid peroxides in animal tissues by thiobarbituric acid reaction. Anal Biochem 1979; 95(2):351-8. https://doi.org/10.1016/0003-2697(79)90738-3

12. Beutler E. Improved method for the determination of blood glutathione. J Lab Clin Med 1963; 61:882-8.

13. Hussein J, Abo Elmatty D, Medhat D et al. Flaxseed oil attenuates experimental liver hepatitis. Der Pharm Lett 2016; 8(8):142-50.

14. Larsen K. Creatinine assay by a reaction-kinetic principle. Clin Chim Acta 1972; 41:209-17 https://doi.org/10.1016/0009-8981(72)90513-X

15. Hussein J, El-Khayat Z, Abdel Latif $\mathrm{Y}$ et al. Evaluation of brain monoamines in diabetic rats treated with quercetin. J Chem Pharm Res 2014; 6(10): 384-90

16. Ellman GL, Courtney KD, Andres V Jr et al. A new and rapid colorimetric determination of 
acetylcholinesterase activity. Biochem Pharmacol 1961; .7:88-95

https://doi.org/10.1016/0006-2952(61)90145-9

17. El-Yamany NA, Mahmoud SM, Abdel Moneim AE. The Ameliorative Effect of Panax Ginseng Extract on Norepinephrine Dopamine and Serotonin Levels in Different Brain Regions of Alloxan-Induced Diabetic Rats. Egy J Zoo 2004; 43:347-366.

18. Mohamed MI, Sharkawy MA, AbdelRahman T et al. Effect of Panax Ginseng on The Activity of Cholinesterase in Different Tissues of Experimentally-Induced Diabetes in Rats. J Egypt Soc Toxicol 2007; 37: 95-106.

19. Hussein J, El-Naggar M, Badawy E. et al. Homocysteine and Asymmetrical Dimethylarginine in Diabetic Rats Treated with Docosahexaenoic Acid-Loaded Zinc Oxide Nanoparticles. Appl Biochem Biotechnol 2020; 191:1127-39.

https://doi.org/10.1007/s12010-020-03230-z

20. Hussein J, Attia MF, ElBana M et al. Solid state synthesis of docosahexaenoic acid-loaded zinc oxide nanoparticles as a potential antidiabetic agent in rats. Int J Bio Macromol. 2019; 140:130514.

https://doi.org/10.1016/j.ijbiomac.2019.08.201

21. Oh DY, Talukdar S, Bae EJ et al. GPR120 is an omega-3 fatty acid receptor mediating potent antiinflammatory and insulin-sensitizing effects. Cell 2020; 142(5): 687-98.

https://doi.org/10.1016/j.cell.2010.07.041

22. Casañas-Sánchez V, Pérez JA, Fabelo $\mathrm{N}$ et al. Addition of docosahexaenoic acid, but not arachidonic acid, activates glutathione and thioredoxin antioxidant systems in murine hippocampal HT22 cells: Potential implications in neuroprotection. J Neurochem 2014; 131(4): 470-83. https://doi.org/10.1111/jnc.12833

23. Jeong YK, Kim H. A Mini-Review on the Effect of Docosahexaenoic Acid (DHA) on CeruleinInduced and Hypertriglyceridemic Acute Pancreatitis. Int J Mol Sci 2017; 18(11):2239. https://doi.org/10.3390/ijms18112239

24. Li ZG, Zhang W, Grunberger G et al. Hippocampal neuronal apoptosis in type 1 diabetes. Brain Res 2002; 946(2):221-31. https://doi.org/10.1016/S0006-8993(02)02887-1

25. Alvarez-Nölting R, Arnal E, Barcia JM et al. Protection by DHA of early hippocampal changes in diabetes: possible role of CREB and NF- $\kappa$ B. Neurochem Res 2012; 37:105-15. https://doi.org/10.1007/s11064-011-0588-x

26. Merad-Boudia M, Nicole A, Santiard-Baron D et al. Mitochondrial impairment as an early event in the process of apoptosis induced by glutathione depletion in neuronal cells: relevance to Parkinson's disease. Biochem Pharmacol 1998; 56(5):645-55.

https://doi.org/10.1016/S0006-2952(97)00647-3

27. Casanas-Sanchez V, Perez JA, Fabelo N, QuintoAlemany D, Díaz M L () Docosahexaenoic (DHA) modulates phospholipid hydroperoxide glutathione peroxidase (Gpx4) gene expression to ensure self-protection from oxidative damage in hippocampal cells. Front Physiol 2015; 6:203. https://doi.org/10.3389/fphys.2015.00203

28. Arnal E, Miranda M, Barcia J et al. Lutein and docosahexaenoic acid prevent cortex lipid peroxidation in streptozotocin-induced diabetic rat cerebral cortex. Neuroscience 2010; 166(1):271-8. https://doi.org/10.1016/j.neuroscience.2009.12.028

29. Sakai C, Ishida M, Ohba $\mathrm{H}$ et al. Fish oil omega-3 polyunsaturated fatty acids attenuate oxidative stress-induced DNA damage in vascular endothelial cells. PLoS ONE 2017; 12(11): e0187934. https://doi.org/10.1371/journal.pone.0187934

30. Haag M. Essential fatty acids and the brain, Can. J Psychiatry 2003; 48(3):195-203. https://doi.org/10.1177/070674370304800308

31. Schwarzenberg SJ, Georgieff MK. Committee on Nutrition Advocacy for improving nutrition in the first 1000 days to support childhood development and adult health Pediatrics. 2018; 141(2):e20173716. https://doi.org/10.1542/peds.2017-3716 
32. Hashimoto M, Hossain S, Al Mamun A et al. Docosahexaenoic acid: one molecule diverse functions. Cri Rev Biotech 2017; 37(5): 579-97. https://doi.org/10.1080/07388551.2016.1207153

33. Mun JG, Legette LC, Ikonte CJ et al. Choline and DHA in Maternal and Infant Nutrition: Synergistic Implications in Brain and Eye Health. Nutrients 2019; 11(5): 1125. https://doi.org/10.3390/nu11051125

34. Pifferi F, Roux F, Langelier B et al. (n-3) polyunsaturated fatty acid deficiency reduces the expression of both isoforms of the brain glucose transporter GLUT1 in rats. J Nutr 2005; 135(9): 2241-6.

https://doi.org/10.1093/jn/135.9.2241

35. Champeil-Potokar G, Chaumontet C, Guesnetp L et al. Docosahexaenoic acid (22:6n-3) enrichment of membrane phospholipids increases gap junction coupling capacity in cultured astrocytes. Eur J Neurosci 2006; 24(11): 3084-90. https://doi.org/10.1111/j.1460-9568.2006.05185.x

36. Jones CR, Arai T, Rapoport SI. Evidence for the involvement of docosahexaenoic acid in cholinergic stimulated signal transduction at the synapse. Neurochem Res. 1997; 22:663-670. https://doi.org/10.1023/A:1027341707837

37. Rapoport SI, Ramadan E, Basselin M. Imaging plasma docosahexaenoic acid (DHA) incorporation into the brain in vivo as a biomarker of brain DHA: Metabolism and neurotransmission. OCL 2011; 18(5): 246-50.

https://doi.org/10.1051/ocl.2011.0396

38. Kim HY, Spector AA, Xiong ZM. A synaptogenic amide N-docosahexaenoyl-ethanolamide promotes hippocampal development.

Prostaglandins Lipid Med 2011; 96(1-4):114-120. https://doi.org/10.1016/j.prostaglandins.2011.07.002

39. Zimmer L, Hembert S, Durand G et al. Chronic n3 polyunsaturated fatty acid diet-deficiency acts on dopamine metabolism in the rat frontal cortex: a microdialysis study. Neurosci Lett 1998; 240(3):177-181. https://doi.org/10.1016/S0304-3940(97)00938-5

40. Mathieu G, Denis S, Langelier B et al. DHA enhances the noradrenaline release by SH-SY5Y cells. Neurochem Int 2010; 56(1):94-100. https://doi.org/10.1016/j.neuint.2009.09.006

41. Onuki Y, Morishita M, Chiba $\mathrm{Y}$ et al. Docosahexaenoic acid and eicosapentaenoic acid induce changes in the physical properties of a lipid bilayer model membrane. Chem Pharm Bull 2006; 54(1):68-71. https://doi.org/10.1248/cpb.54.68

42. Hashimoto M, Hossain S, Shimada T, Shido O. Docosahexaenoic acid-induced protective effect against impaired learning in amyloid beta-infused rats is associated with increased synaptosomal membrane fluidity. Clin Exp Pharmacol Physiol 2006; 33(10): 934-9. https://doi.org/10.1111/j.1440-1681.2006.04467.x

43. Bandarra NM, Lopes PA, Martins SV et al. Docosahexaenoic acid at the sn-2 position of structured triacylglycerols improved n-3 polyunsaturated fatty acid assimilation in tissues of hamsters. Nutr Res 2016; 36(5):452-63. https://doi.org/10.1016/j.nutres.2015.12.015

44. Marcheselli VL, Hong S, Lukiw WJ et al. Novel docosanoids inhibit brain ischemia-reperfusionmediated leukocyte infiltration and proinflammatory gene expression. J Biol Chem 2003; 278(44): 43807-17.

https://doi.org/10.1074/jbc.M305841200

45. Zhao Y, Calon F, Julien C et al. Doco-sahexaenoic acid-derived neuro-protectin D1 induces neuronal survival via secretase and PPARc-mediated mechanisms in Alzheimer's disease models. PLoS One 2011; 6(1): e15816. https://doi.org/10.1371/journal.pone.0015816 


\title{
Dokosaheksaenoična kiselina moduliše oksidativni stres i nivo monoamina u mozgu miševa sa dijabetesom izazvanim streptozotocinom
}

\author{
Sahar Mohamed Mahmoud ${ }^{1}$, Yasmin Abdel Latif², Hisham Orban², Amr Mahmoud Ibrahim², Jihan Hussein² \\ ${ }^{1}$ Departman za zoologiju, Fakultet nauka, Univerzitet u Kairu, Kairo, Egipat \\ ${ }^{2}$ Departman za medicinsku biohemiju, Nacionalni istraživački centar, Kairo, Egipat
}

\section{S A ŽETAK}

Prevalencija dijabetesa melitusa (DM) raste u mnogim zemljama. Niža prevalencija dijabetesa melitusa tipa 2 i ostalih poremećaja metabolizma šećera primećena je kod populacija koje konzumiraju veće količine n-3 polinezasićenih masnih kiselina, koje se uglavnom nalaze u ribi. Dokosaheksaenoična kiselina (DHA) je važan signalni molekul neophodan za kontinuirano održavanje funkcije mozga od strane centralnog nervnog sistema. Cilj ovog istraživanja bilo je rasvetljavanje uloge DHA u kontroli vrednosti glikemije i modeliranju oksidativnog/antioksidativnog statusa $i$ nivoa transmitera u mozgu pacova sa dijabetesom. Dijabetes je bio izazvan jednom dozom subkutano date injekcije streptozotocina (STZ) $(6,0 \mathrm{mg}$ $/$ 0,5 $\mathrm{ml} / 100 \mathrm{~g}$ telesne težine). Eksperimentalni pacovi soja Vistar, muškog pola, nasumično su podeljeni $\mathrm{u}$ četiri grupe: kontrolnu grupu, DHA grupu, miševe kod kojih je dijabetes izazvan strptozotocinom $\mathbf{i}$ STZ+DHA grupu. Svi miševi ubijeni su nakon mesec dana i urađena je kontrola glukoze, nivoa insulina, oksidativnog stresa u mozgu, a takođe su provereni i nivoi monoamina. Davanje DHA značajno je poboljšalo vrednosti glukoze nakon noćnog gladovanja i nivoe insulina u poređenju sa DHA+STZ grupom i smanjilo je nivo 8-hidroxi-2'-deoksigvanozina u urinu. Pored toga, tretiranje miševa sa dijabetesom izazvanim streptozotocinom dokosaheksaenoičnom kiselinom pokazalo je smanjenje sadržaja malondialdehida i poboljšanje proizvodnje proteina u toku oksidacije, kao i značajno povećanje sadržaja glutationa u mozgu pacova tretiranih pomoću DHA+STZ. Takođe, došlo je i do smanjenja nivoa monoamina u mozgu pacova. U zaključku: DHA je modulisala nivoe povećanog oksidativnog stresa i neurotranransmitera, kao i aktivnost acetilholinesteraze u mozgu pacova sa dijebetesom, kroz povećanje nivoa insulina u serumu.

Ključne reči: dijabetes, dokosaheksaenoična kiselina, oksidativni stres, neurotransmiteri, insulin 